\title{
Re M (Children)
}

Court of Appeal: Sir James Munby P, Arden and Singh LJJ, 20 December 2017

[2017] EWCA Civ 2164

Estranged parents - transsexual father - Ultra-Orthodox Judaism - contact best interests - Article 9 ECHR

In $J v B$ (Ultra-Orthodox Judaism: Transgender) [2017] EWFC 4, J and B, an Ultra-Orthodox Jewish couple, had parted in 2015 when J decided to live as a woman. From then on, though J sought to remain an Orthodox Jew, keeping kosher and attending synagogue when she could do so, she had had no contact with the children because of the attitude of the Charedi community to transsexuals. Peter Jackson J had decided, with regret, to refuse her application for direct contact and, instead, made an order for indirect contact four times a year. J appealed.

The Court of Appeal concluded, in short, that Jackson J had not struck the correct balance between the needs of the children, the wishes of J, the wishes of the mother and the views of the Charedi community generally. In its view, two principles were central to the issues before it: the core principle that the function of the judge in a case like this is to act as the judicial reasonable parent, judging the child's welfare by the standards of reasonable men and women today; and a positive duty to attempt to promote contact, under which the judge was obliged to consider all alternatives before abandoning hope of achieving some contact, to be careful not to come to a premature decision and to stop contact only as a last resort. The court was of the opinion that the approach should have been no different merely because religious belief, practice or observance was in play. Jackson J had not asked a number of highly pertinent questions about such matters as the effects of behaviour that was, or might be, unlawfully discriminatory and how the outcome could meet even the mediumlet alone the long-term needs and interests of the children. In short, he gave up too easily and decided the question of direct contact then and there.

As to the issue of Article 9 and the right of the Charedi community to manifest beliefs that resulted in the exclusion of young children from the rest of the community, this did not meet the Convention's criteria for protection under Article 9. On the more general issue of whether a direct contact order would violate the community's Article 9 rights, such an order would be made only after careful consideration with the parties of the children's best interests. If this involved any interference with any rights of the community to manifest their religious beliefs, it was doubted that there would be any violation of the community's rights under Article 9. This was because the court, as an organ of the state, had decided that a restriction of their right to express their religious beliefs served the legitimate aim of protecting the children's rights to have 
contact with their father and thus to enjoy family life with him, which rights were vital to their wellbeing. The appeal was allowed and the case remitted for a further hearing. [Frank Cranmer]

doi:10.1017/So956618X18000741

\author{
Re Newcastle under Lyme Cemetery \\ Lichfield Consistory Court: Eyre Ch, 27 December 2017 \\ [2017] ECC Lic 6 \\ Exhumation - exceptionality
}

In 1995 Mr Bristeir's remains were buried in plot 15000 of the cemetery. It was intended that his wife's remains should join his when her time came. Her two brothers purchased the burial rights for the adjoining plot 14999 in order that they might be interred there in due course. One brother was buried in the appropriate plot, but the other brother was mistakenly buried in plot 15000 . This mistake only came to light in 2017, on the day before Mrs Bristeir's funeral, when it was discovered as part of the preparations for the interment. $\mathrm{Mr}$ and Mrs Bristeir's only daughter was then required to make a swift decision about whether to inter her mother's remains in plot 14999 with those of her brother or to postpone the planned funeral while an exhumation faculty was sought. She chose the former option.

Having regretted her decision, within ten days Mr and Mrs Bristeir's daughter took steps to petition for a faculty for the exhumation of the remains of her mother and her uncle for their re-interment in the plots for which they were originally intended. The chancellor was satisfied that the exhumation of the uncle's remains fell squarely within the mistake category set down in re Blagdon Cemetery [2002] Fam 299, but the exhumation of Mrs Bristeir's remains was not so straightforward. No mistake had been made, but rather the daughter had made a deliberate decision to inter the remains in plot 14999 . Nevertheless, the background to that decision was such that exceptional circumstances existed which justified a departure from the norm of permanence of Christian burial. The daughter had had to make the decision at extremely short notice at a time when she was bereaved and had no other family member to whom she could turn for support and advice. The decision itself was a response to the mistaken burial of the uncle in plot 15000 . The faculty was granted. [RA] 